\title{
The Lac Courte Oreilles
}

\section{Band of Lake Superior Ojibwe}

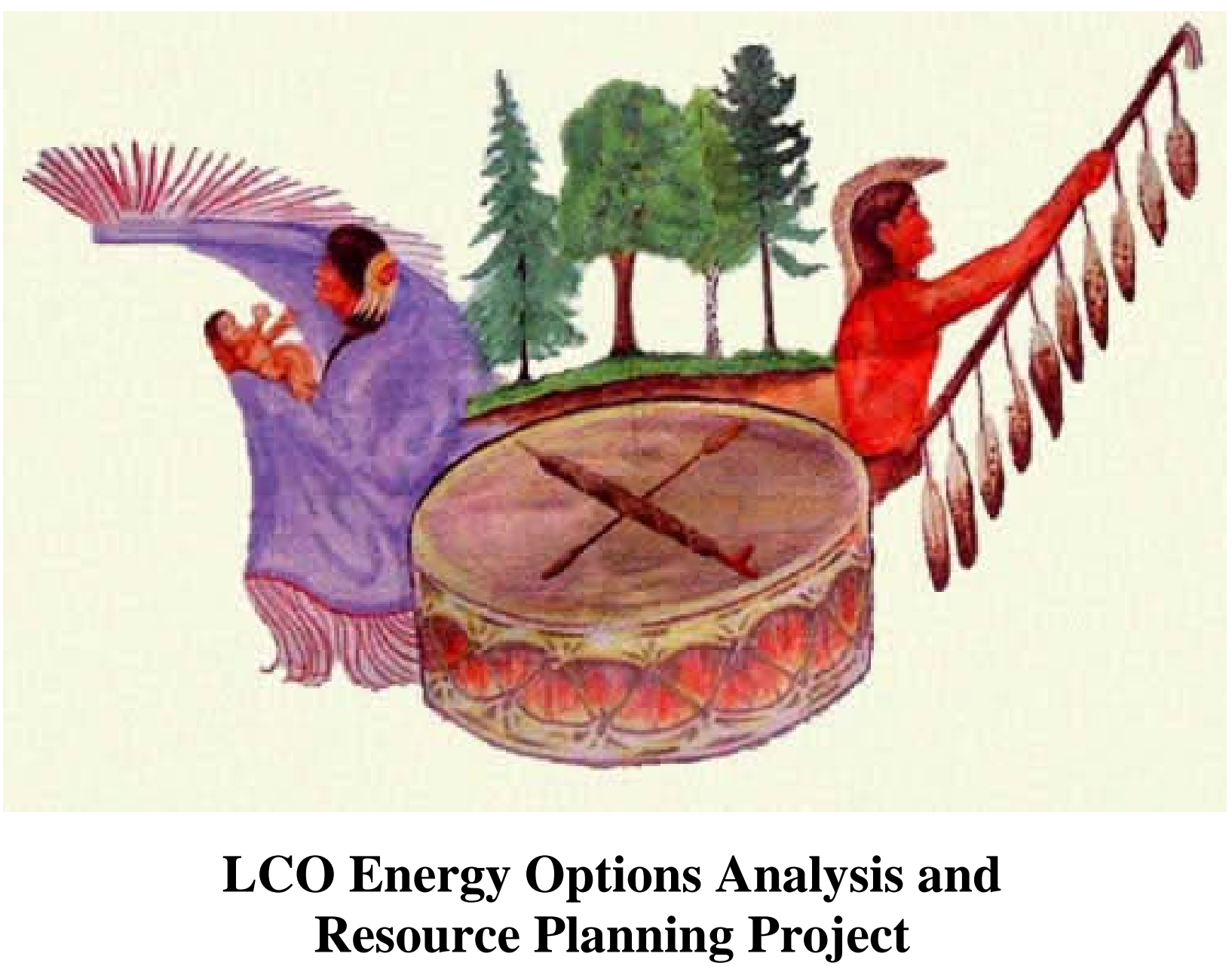

Funding received from the Department of Energy Tribal Energy Program Department of Energy Grant \# DE-FG36-07G017088 
Table of Contents

Executive Summary

Project Overview

Objectives

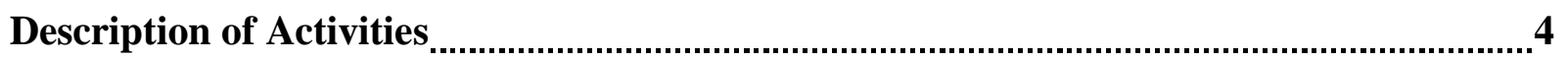

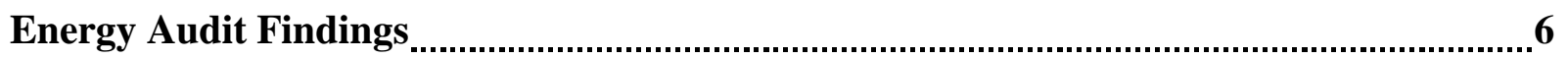

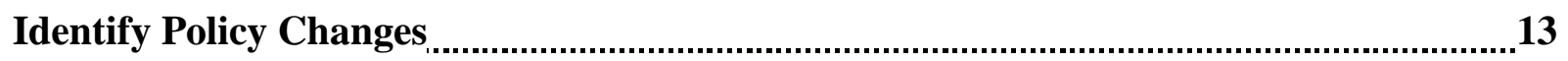

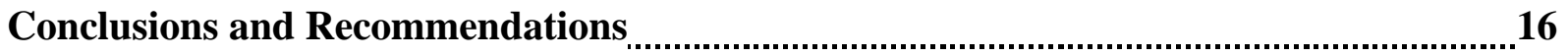

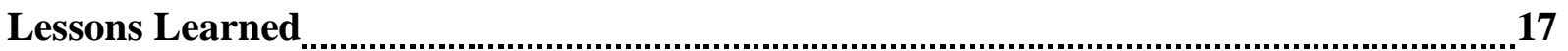

Attachment A Casino and Convention Center Lighting Proposal from MidWest Lighting Attachment B Casino and Convention Center Lighting Proposal from Energy Solutions Attachment C Casino and Convention Center Lighting Proposal from United Electric Attachment D Casino and Convention Center Lighting Proposal Summary Attachment E Conservation Efforts Ideas Attachment F Renewable Energy Option Sites 
The Lac Courte Oreilles Tribe has resolved to protect and honor Nokomis Akin (Grandmother Earth) by utilizing only what is needed. We, the Anishinaabeg, embark on a path to sustainable living and independence for ourselves and our generations yet to come. This will be achieved by implementing systemic conservation measures and the development of sustainable energy.

\section{Executive Summary}

The Lac Courte Oreilles Tribe applied for first step funding in 2007 and was awarded in October of that year. We wanted to perform an audit to begin fulfilling two commitments we made to our membership and resolutions that we adopted. One was the Kyoto Protocol and reduce our carbon emissions by $25 \%$ and to produce $25 \%$ of our energy by sustainable means. To complete these goals we needed to begin with first assessing what our carbon emissions are and begin taking the steps to conserve on the energy we currently use. The First Step Grant gave us the opportunity to do this. Upon funding the Energy Project was formed under the umbrella of the LCO Public Works Department and Denise Johnson was hired as the coordinator. She quickly began fulfilling the objectives of the project. Denise began by contact the LCO College and hiring interns who were able to go to each Tribal entity and perform line logging to read and document the energy used for each electrical appliance. Data was also gathered for one full year from each entity for all their utility bills (gasoline, electric, natural gas, fuel oil, etc.).

Relationships were formed with the Green Team and other Green Committees in the area that could assist us in this undertaking. The Energy Task Force was of great assistance as well recommending other committees and guidance to completing our project.

The data was gathered, compiled and placed into spreadsheets that would be understandable for anyone who didn't have a background in Renewable Resources. While gathering the data Denise was also looking for ways to conserve energy usage, policies changes to implement and any possible viable renewable energy resources. Changes in the social behaviors of our members and employees will require further education by workshops, energy fairs, etc.. This will be looked into and done in coordination with our schools. The renewable resources seem most feasible are wind resources as well as Bio Mass both of which need further assessment and funding to do so will be sought. While we already are in ownership of a Hydro Dam it is currently not functioning to its full capacity we are seeking operation and maintenance firm proposals and funding sources.

One of our biggest accomplishment this project gave us was our total Carbon Emissions 9989.45 tons, this will be the number that we will use to base our reductions from. It will help us achieve our goals we have set for ourselves in achieving the Kyoto Protocol and saving our Earth for our future generations. Another major accomplishment and lesson learned is we need to educate ourselves and our people on how to conserve energy to both impact the environment and our own budgets. 


\section{Project Overview}

The Lac Courte Oreilles (LCO) Energy Analysis Project will perform an energy audit to gather information on the Tribe's energy usage and determine the carbon emissions. By performing the audit we will be able to identify areas where conservation efforts are most viable and recommend policies that can be implemented. These steps will enable LCO to begin achieving the goals that have been set by the Tribal Governing Board and adopted through resolutions. The goals are to reduce emissions by $25 \%$ and to produce $25 \%$ of its energy using sustainable sources.

\section{Objectives}

The project objectives were very definitive to assist the Tribe in achieving its goals; reducing carbon emissions and obtaining a sustainable source of energy. The following were the outlined objectives:

- Coordinate LCO’s current and future conservation and renewable energy projects

- Establish working relationships with outside entities to share information and collaborate on future projects

- Complete energy audit and analyze LCO’s energy load and carbon emissions

- Identify policy changes, education programs and conservation efforts which are appropriate for the LCO Reservation

- Create a plan to identify the most cost effective renewable energy options for LCO

\section{Description of Activities Performed}

By collaborating with the LCO College programs, Work Based Learning and Internship program we had the assistance of two interns to assist with the line logging of the separate buildings. To better describe the activities performed we will first identify the objective that they are linked too.

\section{Coordinate LCO's current and future conservation and renewable energy projects}

While undertaking the audit process in the individual buildings Denise and the interns were able to note the type of equipment being used and what they were using in the means of energy. This allowed her to make a more educated recommendation to the department. There was also a lighting assessment done of all the buildings and recommendations made on them. These options will be addressed under feasibility and taken under consideration by the community and the Tribal Governing Board. The audit revealed the largest energy consumers and plans will be made to reduce the consumption at those facilities. 


\section{Establish working relationships with outside entities to share information and collaborate on future projects}

Denise began contacting the other departments and entities to gather all their conservation and energy related policies. Physical audits were done on each entity and office appliances were catalogued, lighting was assessed and options for running a more sustainable "green" business evolved. Recommendations for the Casino to change out lighting along with the rebates it would receive from Xcel Energy and the amount saved per year was assessed.

She has been involved with the College and getting acquainted with its recycling process. She coordinated, as chair, a community Energy/Sustainability Fair with the LCO College and others from the community. The Fair was a success and is going to be continued and improved upon in future years to come. Also, Denise worked with the college to employ several interns which helped out with the audit while serving as a learning environment for students wishing to expand their horizons and gain employment skills. This will be continued also.

At this time she has also been involved in assisting the LCO School with its goal of becoming green. The Bureau of Indian Education has mandated their schools to go "green". Denise wrote a brief plan for the school on their energy usage, carbon footprint and ideas to get their program started. This is ongoing.

The LCO Hydro Project has been a topic of focus also. North American Hydro has come back to the table to work with the tribe on possibly becoming the main operations and management team. This also is ongoing and is an option for feasibility in the future for increased/changed generation with newer technology.

The Public Works department has been very active in leading the way with energy efficiency, conservation and green practices. Lighting efficiency was addressed and updates were made, recycling was made mandatory and styrofoam and paper cups were banned from the coffee area making it each employee bring their own mug with extra's donated for meeting use.

The coordinator, Denise Johnson, joined the Chequamegon Bay Green Team led by the Alliance for Sustainability. She and interns attended many information meetings as well attended the Wisconsin Sustainable Business Conference and workshops to gather information on green business. This is ongoing. 


\section{Complete energy audit and analyze LCO's energy load and carbon emissions}

With the assistance of interns from the LCO College an energy audit was performed by going into each entity to catalogue equipment, lighting as well as office consumptive behaviors. A power meter was used to determine the kilowatts used and employees were interviewed on when items were consuming power or turned off. With the knowledge that assessment of energy is always a moving target, it has been determined that dollar expenditures are around 1.5 million USD and the Tribes carbon footprint is around 10,000 tons of CO2 annual emissions. A breakdown of each individual energy unit is available in the PowerPoint. Here is the data:

- LCO's total carbon emission is 9989.45 tons $\mathrm{CO} 2$

* Electric $\quad 9,415,125 \mathrm{KWH}$

* Natural Gas 272,857 Therms

* Propane 54,355.9 Gallons

* Gasoline 132,395.7 Gallons

* Diesel 2123.7 Gallons

- LCO's total dollars spent yearly is $\$ \mathbf{1 , 5 2 5 , 7 3 1}$

* Electric $\quad \$ 667253.51$

* Natural Gas $\quad \$ 343,725.50$

* Propane \$113,600.14

* Gasoline $\quad \$ 401,151.81$

* Diesel \$6,647.26

- LCO’s Commercial Sales Emissions is 19,031.59 
The individual break down of these per Tribal Entity is as follows:

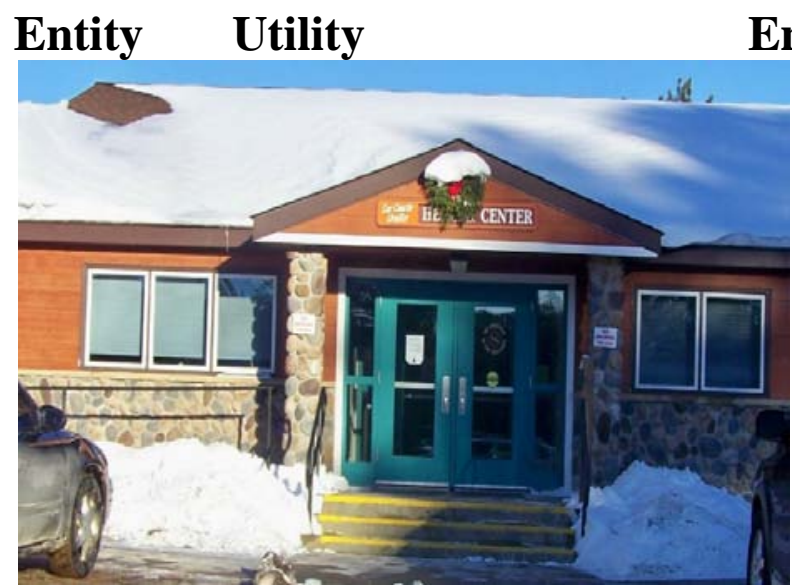

\section{Clinic}

Energy Units

Cost

Jump River

WEnergies

Gasoline

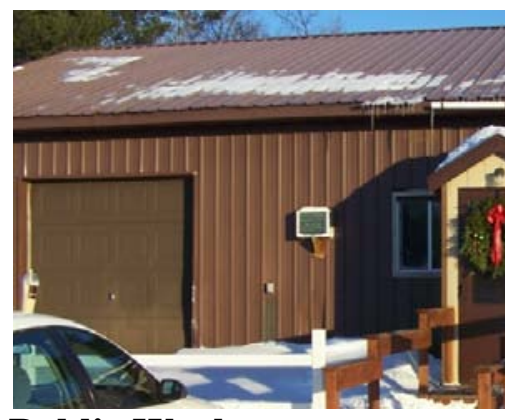

Public Works

Jump River

Xcel Energy

WEnergies

Tru-Gas

Gasoline

$$
\begin{aligned}
255009.00 & \text { Kwh } \\
8240.00 & \text { Therms } \\
1875.00 & \text { Gallons }
\end{aligned}
$$

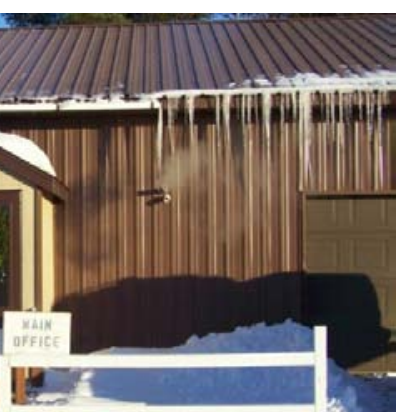

$$
\begin{aligned}
100057.00 & \text { Kwh } \\
222640.00 & \text { Kwh } \\
350.00 & \text { Therms } \\
1272.80 & \text { Gallons } \\
5133.00 & \text { Gallons }
\end{aligned}
$$

$\$ 16,482.81$

$\$ 4,395.28$

$\$ 4,811.15$

$\$ 10,811.48$

$\$ 16,247.65$

$\$ 478.18$

$\$ 2,259.73$

$\$ 17,229.09$

\section{Hatchery}

Jump River

Tru-Gas

WEnergies

Gasoline

$\begin{aligned} 11983.00 & \text { Kwh } \\ 884.80 & \text { Gallons } \\ 1054.00 & \text { Therms } \\ 1875.00 & \text { Gallons }\end{aligned}$

$\$ 1,620.50$

$\$ 1,406.84$

$\$ 1,315.37$

$\$ 4,811.15$ 

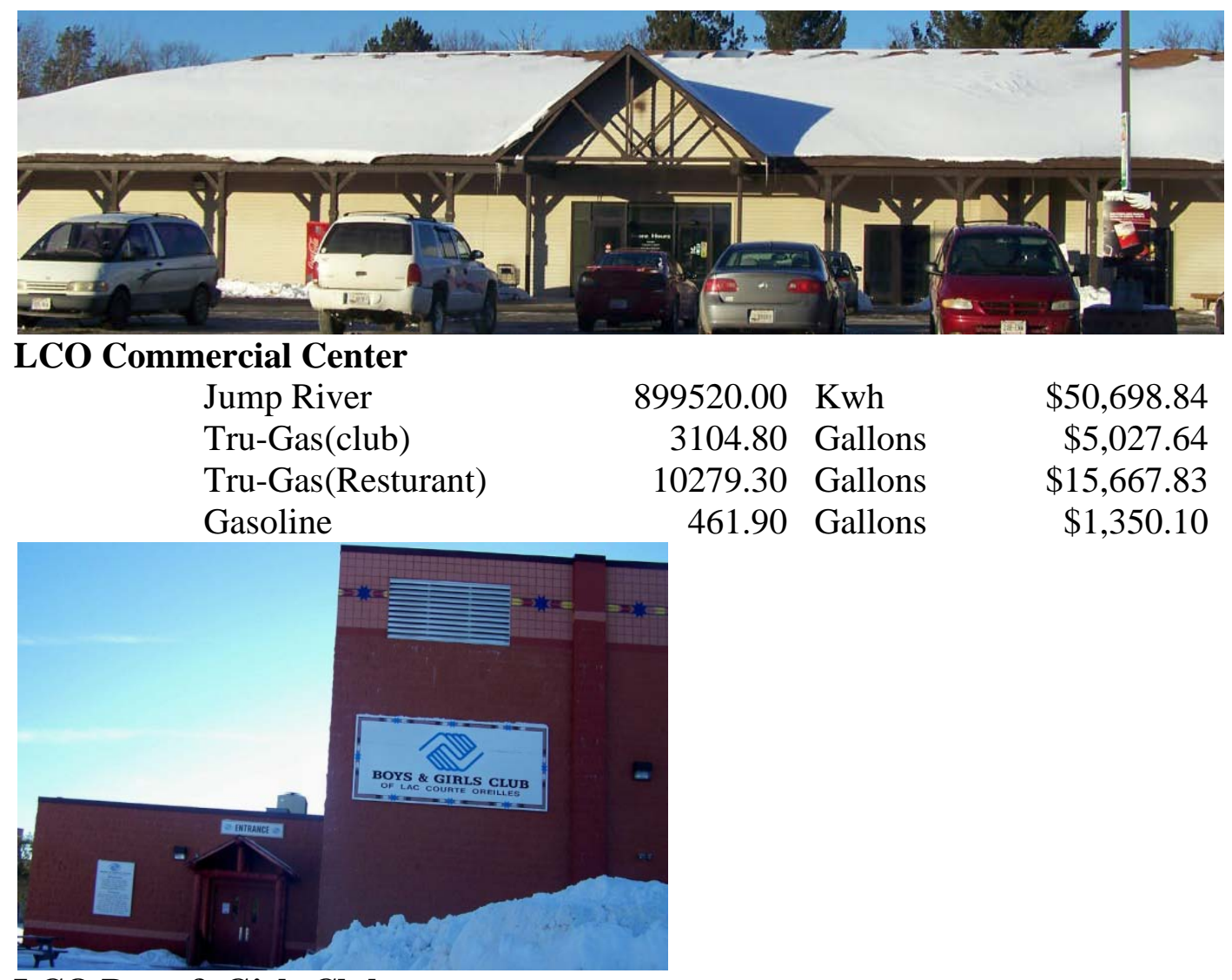

LCO Boys \& Girls Club

Jump River

WEnergies

Gasoline

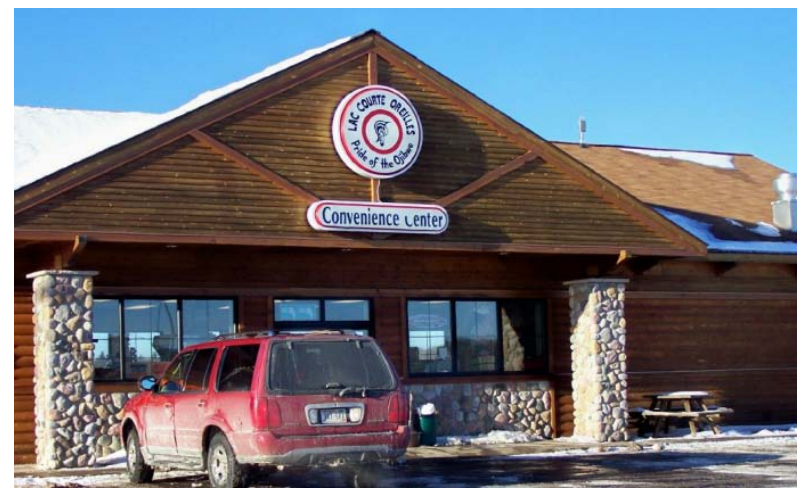

LCO Convience Center

Output

Xcel Energy

WEnergies

Tru-Gas

Input

Diesel

Premium

Regular

\subsection{Kwh \\ 7704.00 Therms 480.30 Gallons}

$\$ 11,333.05$

$\$ 9,117.00$

$\$ 1,519.52$
$\$ 22,269.20$

$\$ 6,991.38$

$\$ 1,098.00$

1500.00 Gallons

52121.00 Gallons

$\$ 169,747.11$

47964.00 Gallons

$\$ 151,130.74$

1297810.00 Gallons

$\$ 3,794,745.61$ 


\section{Birth to Three}

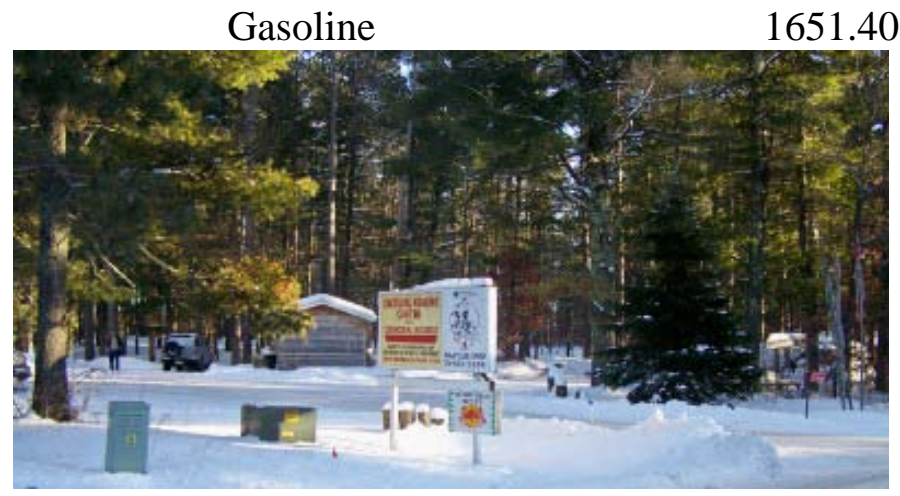

Gallons

$\$ 4,085.74$

Big Drum

Jump River

Tru-Gas
3984.00 Kwh

1651.60 Gallons

436.40 Gallons

780.30 Gallons

Gasoline

Higher Education/Employment

Gasoline

3020.70 Gallons

871.00 Kwh

1595.00 Therms

3982.30 Gallons
$\$ 885.99$

$\$ 2,971.31$

$\$ 1,106.00$

$\$ 2,066.88$

$\$ 8,504.38$

$\$ 373.68$

$\$ 1,848.83$

$\$ 14,675.63$

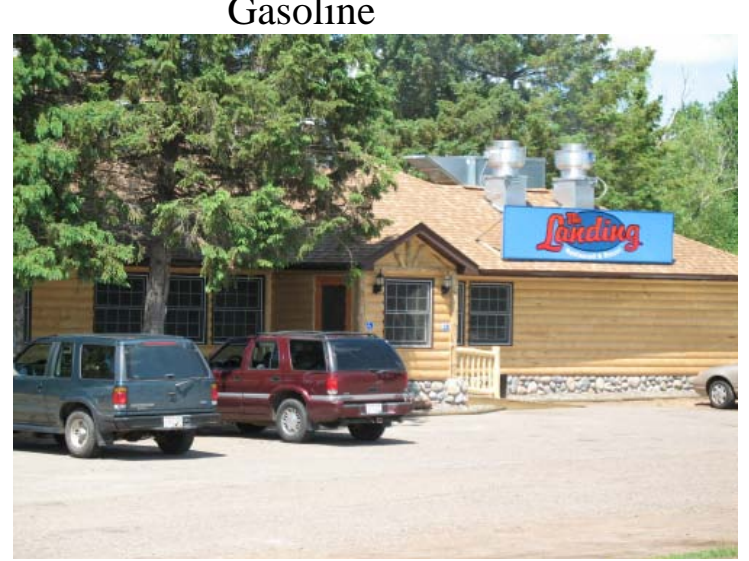

The Landing

Jump River

Tru-Gas

Northern Lake Co-op Gas

Gasoline
225196.00 Kwh

13354.40 Gallons

11734.20 Gallons

181.30 Gallons
$\$ 21,983.21$

$\$ 29,762.93$

$\$ 37,602.58$

$\$ 527.50$ 


\section{Medical Vouchers}

Gasoline

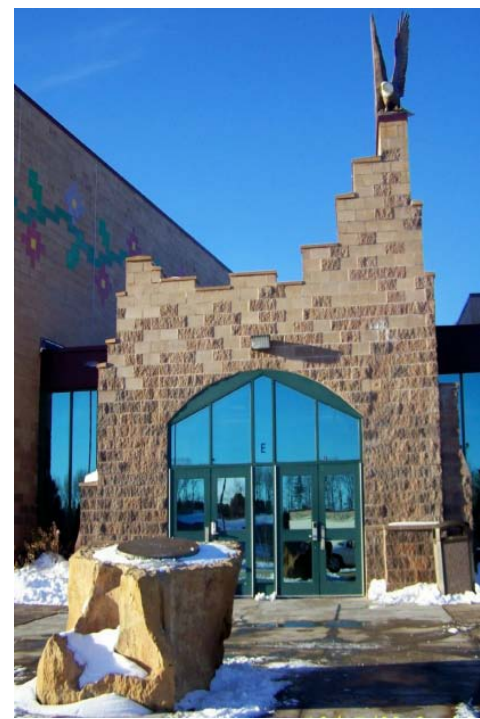

LCO K-12 School

Jump River

WEnergies

Gasoline

$$
\begin{aligned}
1099865.00 & \text { Kwh } \\
97529.00 & \\
19406.30 & \text { Gallons }
\end{aligned}
$$

$$
\begin{aligned}
38448.00 & \text { Kwh } \\
96.70 & \text { Gallons } \\
7905.00 & \text { Therms } \\
2713.40 & \text { Gallons }
\end{aligned}
$$

Gasoline

\section{Gaming Commission}

Gasoline

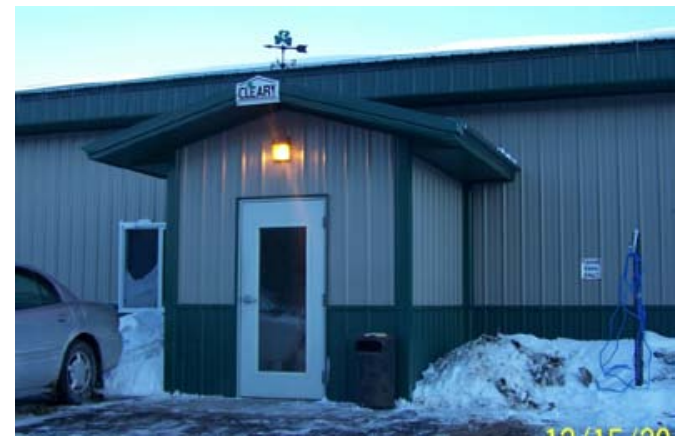

Community Development Center

Jump River

WEnergies

Gasoline
22524.00 Kwh

13018.00 Therms

12.10 Gallons
316.40 Gallons

$\$ 70,841.62$

$\$ 102,348.52$

$\$ 74,322.74$

$\$ 3,546.62$

$\$ 164.39$

$\$ 4,012.27$

$\$ 7,361.36$

$\$ 815.94$
$\$ 1,861.52$

$\$ 1,219.25$

$\$ 32.17$ 


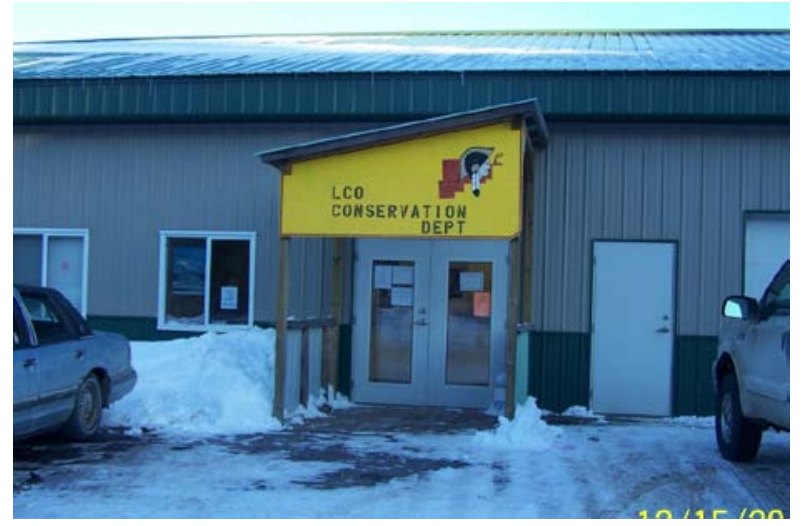

\section{Conservation}

Jump River

WEnergies

Gasoline

$$
\begin{aligned}
10131.00 & \text { Kwh } \\
1127.00 & \text { Therms } \\
8106.60 & \text { Gallons }
\end{aligned}
$$

$\$ 1,137.26$

$\$ 1,333.87$

$\$ 22,670.12$

\section{Oakwood Haven}

Jump River

Tru-Gas

Gasoline
51621.00 Kwh

1929.60 Gallons

796.20 Gallons
$\$ 4,698.73$

$\$ 3,241.12$

$\$ 2,285.11$

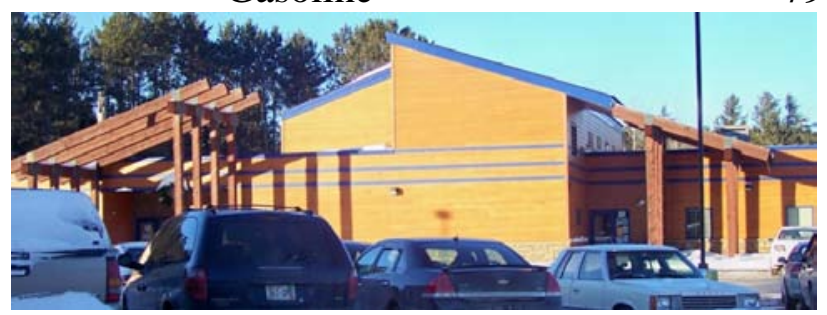

\section{Tribal Office}

Jump River

WEnergies

Gasoline

$$
\begin{aligned}
400698.00 & \text { Kwh } \\
12396.00 & \text { Therms } \\
4914.60 & \text { Gallons }
\end{aligned}
$$

$\$ 24,510.38$

$\$ 12,567.46$

$\$ 14,856.56$
$\$ 3,978.02$

$\$ 5,731.52$

$\$ 3,030.92$

$\$ 48,333.33$ 


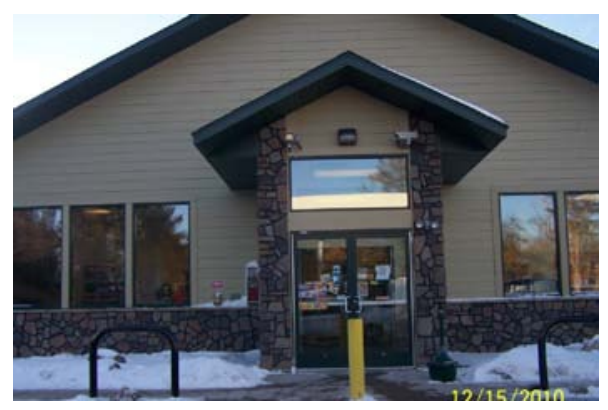

LCO Quickstop

Output

Jump River

Tru-Gas

Input

Diesel

Premium

Regular

\section{Cranberry Marsh}

Jump River

Medical Gasoline

Gasoline

\section{Police Department}

Gasoline

\section{HydroDam}

North Central Power Co.

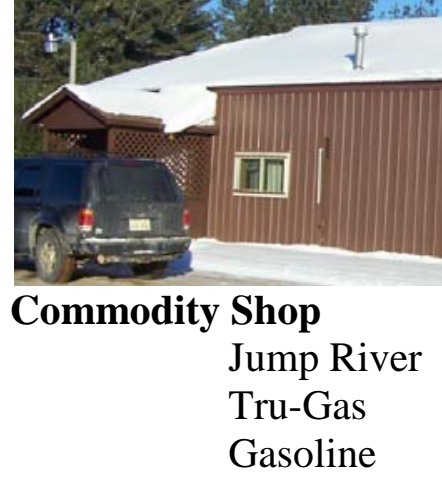

Family Services

Gasoline
7242.00 Kwh

$\$ 887.37$

21007.00 Gallons

$\$ 60,443.58$

9754.80 Gallons

$\$ 30,931.75$

119546.00 Kwh

1653.40 Gallons

$\$ 10,705.42$

$\$ 4,193.50$

$\$ 115,983.22$

$\begin{array}{rrr}30883.00 & \text { Gallons } & \$ 94,873.76 \\ 658828.00 & \text { Gallons } & \$ 1,921,638.00\end{array}$

$\begin{array}{rrr}30883.00 & \text { Gallons } & \$ 94,873.76 \\ 658828.00 & \text { Gallons } & \$ 1,921,638.00\end{array}$

$\$ 8,415.94$

$\$ 3,319.89$

$\$ 4,777.85$

$\$ 108.34$

41.10 Gallons

$\$ 4,594.87$ 


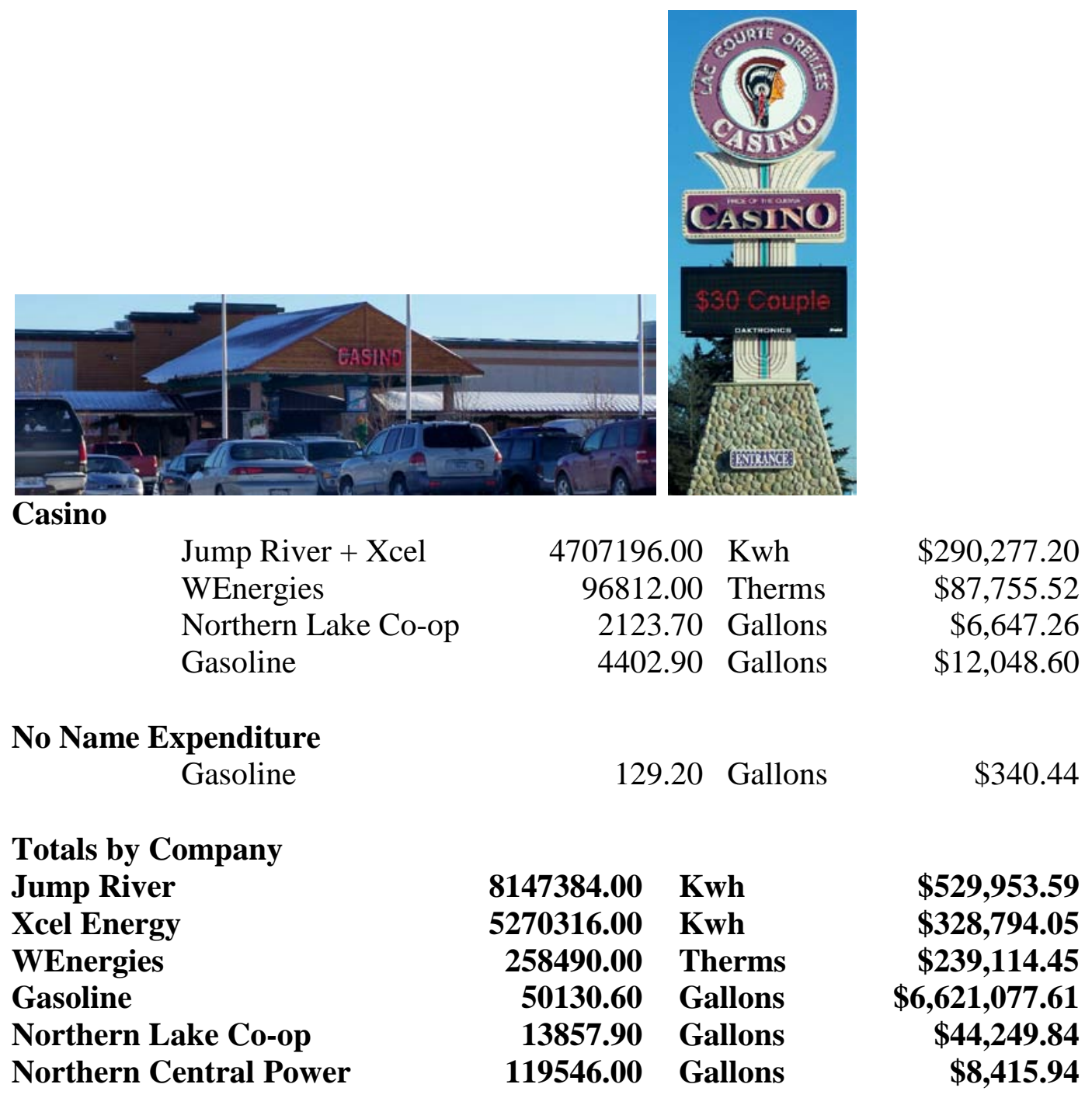

\section{Identify policy changes, education programs and conservation efforts which are appropriate for the LCO Reservation}

\section{Conservation/Efficiency}

LCO Public Works has chosen to lead by example and began its conservation efforts aggressively. The lighting audit suggested changing the fluorescent bulbs that were installed to the T8's in both the office and SBR building. The new fixtures and bulbs were installed with the assistance of a small but essential rebate from Xcel and Focus on Energy and the expected savings for Public Works will continue to assist in paying for the installation costs for another year after that a minimum savings of $\$ 1,500.00$ is expected. Public Works also started recycling their office materials; i.e., paper, soda cans, soda bottles etc... This also provided a small savings on the garbage bill and has reduced the pick-up from twice a month to once a month. In coordination with the line logging data many smaller items have been exchanged for non-electric items or are unplugged when not in use. Some machines were left plugged in and only used 
once a month but still used energy (the vampire effect or phantom load), by unplugging them and discontinuing their use altogether also contributed to the electric savings. Public Works also stopped using Styrofoam cups, individual sugar and creamer packets; all employees were asked to bring in their own mug from home and someone donated mugs for guest use. This has saved the department about \$150 for the first year with no longer providing Styrofoam cups for coffee.

The Casino also made some small changes in their lighting for which they received a rebate and more recommendations on their lighting. Three proposals were collected from three separate electric companies; Midwest Electric, Energy Solutions and United Electric included as Attachment a, b and c respectively a summary as attachment d. As you can see a savings per year would be $\$ 19,047$ with a $75 \%$ savings by using MidWest Electric in combination with the LCO Public Works rebates. At this time however we were unable to convince the management to convert to the more energy efficient lighting. We will be seeking the assistance of the Tribal Governing Board to pursue.

Work with each individual entity to determine where changes can be made to increase conservation and efficiency measures in all areas (weatherization, lighting, HVACs). Cost assessment for each entity to determine feasibility and cost justification for possible upgrades. Once the assessment has been completed and documented begin seeking funding sources to complete necessary upgrades.

Continue to establish relationships with local utilities, Focus on Energy, OEI and the Green Team.

Re-establish a weatherization program that will go into both the homes and the businesses. The nearest weatherization program is Indianhead CAP for which the wait list can be up to two years long. We are currently seeking funding to begin training our own Tribal members to perform home energy audit and weatherization of homes for this region.

Begin working with the LCO K-12 School to get the recycling program both in the homes and in the local businesses. By starting with our youth we can convince our elders that recycling works!

An Energy Conservation Program for Residents creating awareness in the form of workshops, flyers and educating the youth on conservation measures.

\section{Policy Changes}

Continue to work with the other agencies that have adopted a Community Sustainability Plan and begin establishing a Lac Courte Oreilles Sustainability Plan that works for the Tribe. The first step is this plan being completed and adopted by the Tribal Governing Board.

Purchasing across the reservation Energy Star appliances and maintaining them to the best of our ability. Become more involved and more aware of the Energy Star policies, programs and savings. 
Implement in all Tribal entities that all offices be required to use energy efficient supplies such as; re-chargeable batteries, recyclable paper, no Styrofoam cups, energy efficient lighting etc... (attachment e renewable energy policy ideas)

\section{Education- recommended avenues to educate all community members}

\section{Primary}

Facilitate: LCO School Education via Renewable World Foundation, LCO Energy Fair, AISES, Earth Day

\section{Higher}

Continue to Partner with LCO College on internships, technical assistance, SLI \& RE program promotion, AISES, LCO Energy Fair

\section{Community}

Natural Step/Peak Oil/Post Carbon Living study circles, community education on efficiency \& conservation, Energy Conservation incentives, Sustainable Community Development

\section{Tribal Employees \& Governing Board}

Educate through various committee work. Incorporate sustainability into all planning and development. Energy Conservation \& Efficiency Education through one on one meetings.

\section{State}

Liaison/Educate with the current Governor's Office of Energy Independence on Native issues surrounding Energy, sustainability, environment

Create a plan to identify the most cost effective renewable energy options for LCO

Renewable Energy Project Exploration for Feasibility- recommendations for which renewable technologies can help to reduce the 1990 emissions of 8351.51 tons of CO2 by 25\% by 2012. (Attachment F Renewable Energy Option Sites)

Hydro:

Assess feasibility of new generation at current facility Assess sites determined by previous DOE evaluation Assess transmission routes for rerouting of grid to reservation community

Wind Assessment:

Public Works Site first Purchase Analysis Equipment

Ongoing monitoring minimum 12 months 


\section{Bio Mass:}

Trane cooperative analysis

Tribal Campus Site

More info on including Bio Refining as part of the Bio Mass process

Hydroxy (waste water)

\section{Bio Diesel:}

Production \& Feasibility

Single Site (TBD)

Input from Casino, Club, The Landing, LCO School

Output to Tribal Fleet to offset emissions

\section{Solar/PV:}

Assess multiple sites: Signor Center, PWPHs, Lodge, Landing, Commercial Center, New Health Center, LCO School, Head Start, and Big Drum

\section{Solar Thermal:}

Assess multiple Sites: Lodge, New Health Center/Fitness Center, The Landing

\section{Geothermal:}

Assess for all new buildings: New Health Center/Fitness Center, New Housing Development

\section{Conclusions and recommendations}

It is concluded that LCO has many areas in which efficiency and conservation could be a viable means for reduction of both dollars and carbon emissions. It is highly recommended that plans be made for individual buildings for efficiency updates and weatherization. By going into each individual building and changing both the appliances and hopefully the employee's daily routines large savings can be made Tribally wide. In the current economy this could mean great things for our community and the bottom line budget for Lac Courte Oreilles and its members. We've also concluded that community education and incentive programs MUST be developed and that feasibility studies MUST begin for renewable energy development and deployment if LCO is to meet its goal for both the Kyoto Protocol and providing $25 \%$ of its own energy through sustainable resources. By more actively seeking out the anemometer loan program and setting them in the most viable wind locations and looking at the other sources cited above LCO WILL meet its goals by both reducing its carbon emissions and introducing other means of getting its electricity to its members. Making power strips in each office mandatory and must be turned off each evening could be a major energy and cost saving step. 


\section{Lessons Learned}

One major lesson learned is the lack of knowledge by our members surrounding energy sources and its impact on the environment and our future generations. Education is urgently needed to our elders and adults; our youth are much more knowledgeable and can take these valuable lessons home and share them. Social behaviors need to be addressed to effectively make energy issues a top priority. If we could make each person aware of the little things they could do that would change their own electric or heating bill the Reservation carbon emissions would decrease possibly dramatically depending on the attention with which the person kept with the changes.

This lesson also includes employees and the Tribal entities we must change the way we look at energy as an endless source and it having no impact on the environment or the Tribe's pocket book. As recommended above having small workshops about how this does affect both and having our children repeat it when they come home should (hopefully) get the message through.

However, the biggest lesson learned through our audit process is the phantom load, UNPLUG THOSE SMALL ELECTRICAL APPLIANCES! If you're not using them they're still drawing power and costing us money it was amazing the cost of a electric three-hole punch machine that was left plugged in. This audit taught us all how wasteful we are and how small changes can truly add up to big ones! 
Midwest proposal to upgrade lighting

\begin{tabular}{|c|c|c|c|c|c|c|c|c|c|c|c|c|}
\hline \multicolumn{13}{|l|}{ EXISTING } \\
\hline Lighting Type & chase bulbs & HID $400 \mathrm{~W}$ & can lights & $\begin{array}{c}B R 65 W \\
\text { flood }\end{array}$ & Candelabra & Can lights & Candelabra & HID $400 \mathrm{~W}$ & $150 P S 23 / C L$ & 65 BR30/FL & 65 BR30/FL & can lights \\
\hline Location & Casino & Casino & Conv Center & Casino & Casino & lounge & Link & Conv Center & Casino & Bingo Hall & Bingo Hall & Conv Center \\
\hline \multirow{6}{*}{$\begin{array}{r}\text { Number of Fixtures } \\
\text { Lamps per Fixture } \\
\text { Fixture Wattage } \\
\text { LF - Load Factor } \\
\text { Annual Operating Hours } \\
\text { Conversion Factor }\end{array}$} & 1700 & 20 & 25 & 54 & 120 & 97 & 140 & 16 & 45 & 12 & 42 & 6 \\
\hline & 1 & 1 & 1 & 1 & 1 & 1 & 1 & 1 & 1 & 1 & 1 & 1 \\
\hline & 11 & 458 & 150 & 65 & 20 & 65 & 20 & 458 & 180 & 65 & 65 & 150 \\
\hline & 1 & 1 & 1 & 1 & 1 & 1 & 1 & 1 & 1 & 1 & 1 & 1 \\
\hline & 8,760 & 1,000 & 4,000 & 8,760 & 8,760 & 8,760 & 8,760 & 2,080 & 2,080 & 3,000 & 3,000 & 2,080 \\
\hline & 1,000 & 1,000 & 1,000 & 1,000 & 1,000 & 1,000 & 1,000 & 1,000 & 1,000 & 1,000 & 1,000 & 1,000 \\
\hline
\end{tabular}

\begin{tabular}{|c|c|c|c|c|c|c|c|c|c|c|c|c|}
\hline kW & 18.7 & 9.2 & 3.8 & 3.5 & 2.4 & 6.3 & 2.8 & 7.3 & 8.1 & 0.8 & 2.7 & 0.9 \\
\hline kWh/Yr Use & 163,812 & 9,160 & 15,000 & 30,748 & 21,024 & 55,276 & 24,528 & 15,246 & 16,848 & 2,340 & 8,190 & 1,872 \\
\hline Average kWh Rate & $\$ 0.070$ & $\$ 0.070$ & $\$ 0.070$ & $\$ 0.070$ & $\$ 0.070$ & $\$ 0.070$ & $\$ 0.070$ & $\$ 0.070$ & $\$ 0.070$ & $\$ 0.070$ & $\$ 0.070$ & $\$ 0.070$ \\
\hline
\end{tabular}

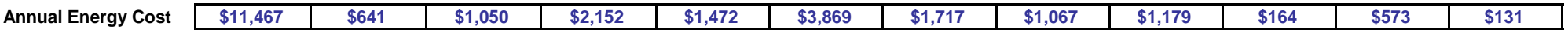

\section{PROPOSED}

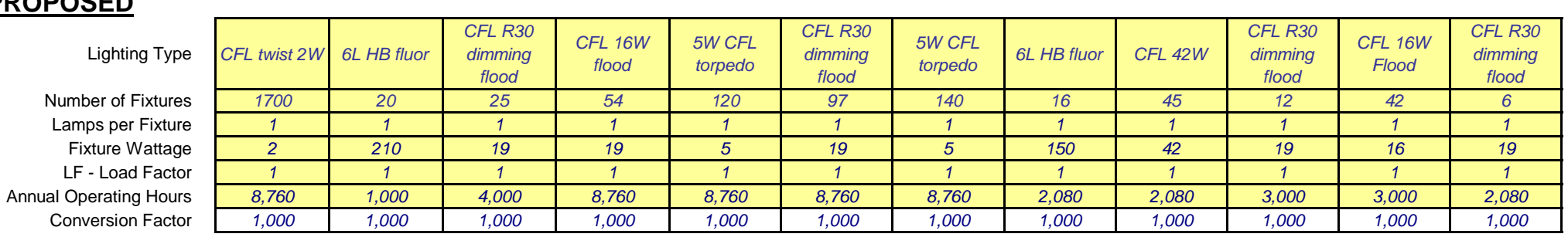

kW

\begin{tabular}{|c|c|c|c|c|c|c|c|c|c|c|c|}
\hline 3.4 & 4.2 & 0.5 & 1.0 & 0.6 & 1.8 & 0.7 & 2.4 & 1.9 & 0.2 & 0.7 & 0.1 \\
\hline $\mathbf{2 9 , 7 8 4}$ & $\mathbf{4 , 2 0 0}$ & $\mathbf{1 , 9 2 0}$ & $\mathbf{9 , 0 2 3}$ & $\mathbf{5 , 2 5 6}$ & $\mathbf{1 6 , 1 1 8}$ & $\mathbf{6 , 1 3 2}$ & $\mathbf{4 , 9 9 2}$ & $\mathbf{3 , 9 3 1}$ & $\mathbf{6 9 0}$ & $\mathbf{2 , 0 1 0}$ & $\mathbf{2 2 9}$ \\
\hline
\end{tabular}

\section{SAVINGS}

\begin{tabular}{|c|c|c|c|c|c|c|c|c|c|c|c|c|}
\hline \multirow{3}{*}{$\begin{array}{r}k W \\
k W h / Y r \text { Use } \\
\text { Annual Energy Cost }\end{array}$} & 153 & 50 & 33 & 25 & 18 & 45 & 21 & 49 & 62 & 06 & 21 & 08 \\
\hline & 134,028 & 4,960 & 13,080 & 21,725 & 15,768 & 39,158 & 18,396 & 10,254 & 12,917 & 1,650 & 6,180 & 1,643 \\
\hline & $\$ 9,382$ & $\$ 347$ & $\$ 916$ & $\$ 1,520$ & $\$ 1,104$ & $\$ 2,741$ & $\$ 1,288$ & $\$ 718$ & $\$ 904$ & $\$ 116$ & $\$ 432$ & $\$ 115$ \\
\hline \multirow{3}{*}{$\begin{array}{r}\text { Project cost Estimate } \\
\text { Incentive } \\
\text { Simple Payback }\end{array}$} & $\$ 9,503$ & $\$ 2,570$ & $\$ 412$ & $\$ 481$ & $\$ 612$ & $\$ 1,598$ & $\$ 714$ & $\$ 2,056$ & $\$ 432$ & $\$ 198$ & $\$ 374$ & $\$ 99$ \\
\hline & $\$ 3,400$ & $\$ 1,200$ & $\$ 100$ & $\$ 216$ & $\$ 240$ & $\$ 388$ & $\$ 280$ & $\$ 960$ & $\$ 225$ & $\$ 48$ & $\$ 168$ & $\$ 24$ \\
\hline & 0.7 & 3.9 & 0.3 & 0.2 & 0.3 & 0.4 & 0.3 & 1.5 & 0.2 & 1.3 & 0.5 & 0.7 \\
\hline
\end{tabular}

Red triangles in the upper right corner means there is a comment explaining the cell. 
Casino and Convention Center

Energy Solutions proposal to upgrade lighting.

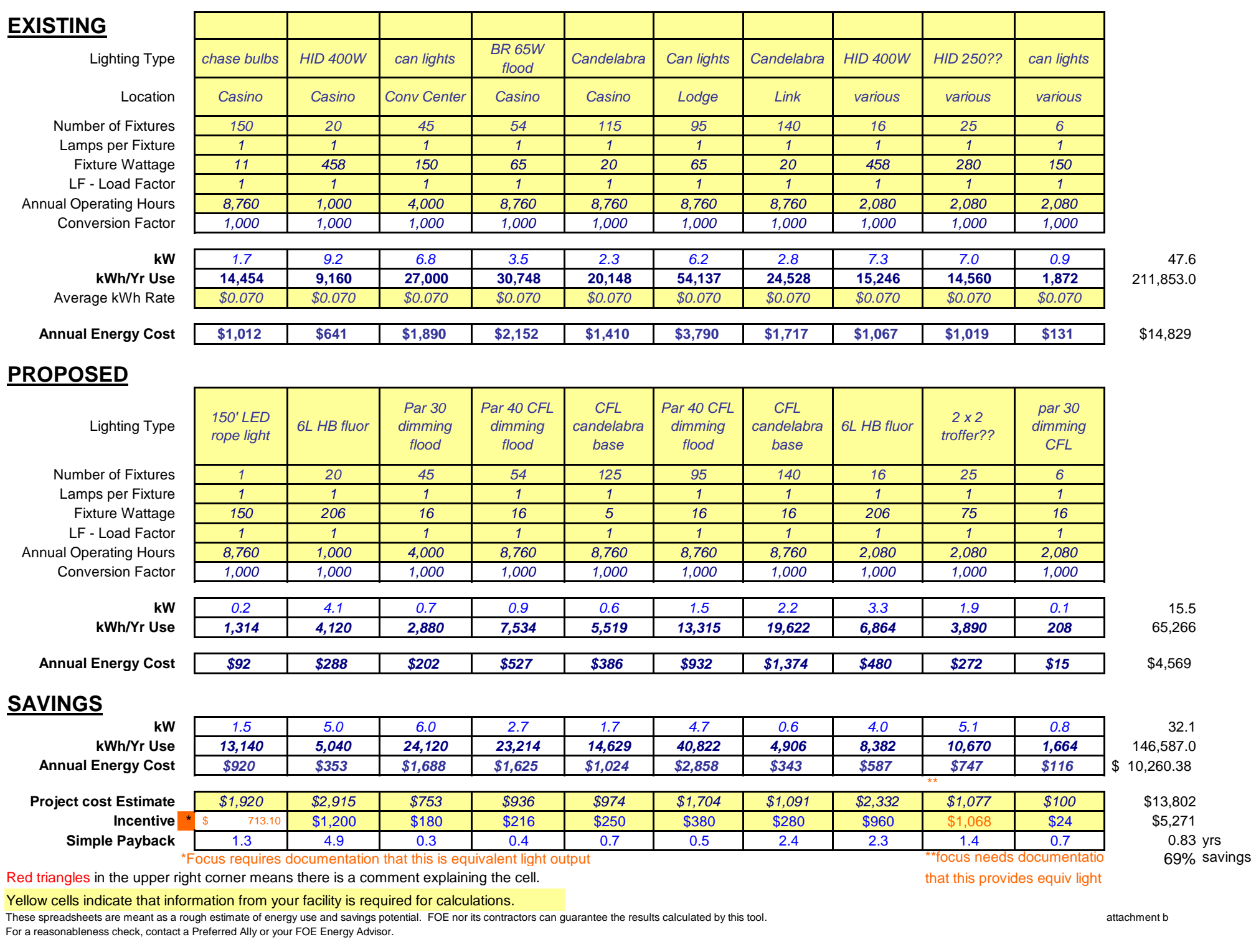




\section{Casino and Convention Center}

United Electric proposal to upgrade lighting.

\begin{tabular}{|c|c|c|c|c|c|c|c|c|c|}
\hline \multicolumn{10}{|l|}{ EXISTING } \\
\hline Lighting Type & chase bulbs & HID $400 \mathrm{~W}$ & can lights & $\begin{array}{l}\text { BR } 65 W \\
\text { flood }\end{array}$ & Candelabra & Can lights & Candelabra & HID $400 \mathrm{~W}$ & can lights \\
\hline \multirow{2}{*}{$\begin{array}{r}\text { Location } \\
\text { Number of Fixtures }\end{array}$} & Casino & Casino & conv center & Casino & Casino & Lodge & Link & various & various \\
\hline & 150 & 20 & 45 & 54 & 115 & 95 & 140 & 16 & 6 \\
\hline \multirow{3}{*}{$\begin{array}{r}\text { Lamps per Fixture } \\
\text { Fixture Wattage } \\
\text { LF - Load Factor }\end{array}$} & 1 & 1 & 1 & 1 & 1 & 1 & 1 & 1 & 1 \\
\hline & 11 & 458 & 150 & 65 & 20 & 65 & 20 & 458 & 150 \\
\hline & 1 & 1 & 1 & 1 & 1 & 1 & 1 & 1 & 1 \\
\hline \multirow{2}{*}{$\begin{array}{r}\text { Annual Operating Hours } \\
\text { Conversion Factor }\end{array}$} & 8,760 & 1,000 & 4,000 & 8,760 & 8,760 & 8,760 & 8,760 & 2,080 & 2,080 \\
\hline & 1,000 & 1,000 & 1,000 & 1,000 & 1,000 & 1,000 & 1,000 & 1,000 & 1,000 \\
\hline \multirow{3}{*}{$\begin{array}{r}\mathbf{k W} \\
\mathbf{k W h} / \mathbf{Y r} \text { Use } \\
\text { Average kWh Rate }\end{array}$} & 1.7 & 9.2 & 6.8 & 3.5 & 2.3 & 6.2 & 2.8 & 7.3 & 0.9 \\
\hline & 14,454 & 9,160 & 27,000 & 30,748 & 20,148 & 54,137 & 24,528 & 15,246 & 1,872 \\
\hline & $\$ 0.070$ & $\$ 0.070$ & $\$ 0.070$ & $\$ 0.070$ & $\$ 0.070$ & $\$ 0.070$ & $\$ 0.070$ & $\$ 0.070$ & $\$ 0.070$ \\
\hline Annual Energy Cost & $\$ 1,012$ & $\$ 641$ & $\$ 1,890$ & $\$ 2,152$ & $\$ 1,410$ & $\$ 3,790$ & $\$ 1,717$ & $\$ 1,067$ & $\$ 131$ \\
\hline
\end{tabular}

\section{PROPOSED}

\begin{tabular}{|c|c|c|c|c|c|c|c|c|c|}
\hline Lighting Type & $\begin{array}{c}\text { Cold } \\
\text { Cathode } 2 W\end{array}$ & $6 \mathrm{~L} \mathrm{HB}$ fluor & $\begin{array}{c}\text { Par } 30 \\
\text { dimming } \\
\text { flood }\end{array}$ & $\begin{array}{c}\text { Par } 40 \text { CFL } \\
\text { dimming } \\
\text { flood }\end{array}$ & $\begin{array}{c}C F L \\
\text { candelabra } \\
\text { base }\end{array}$ & $\begin{array}{c}\text { Par } 40 \text { CFL } \\
\text { dimming } \\
\text { flood }\end{array}$ & $\begin{array}{c}\text { CFL } \\
\text { candelabra } \\
\text { base }\end{array}$ & $6 L$ HB fluor & $\begin{array}{c}\text { par } 30 \\
\text { dimming } \\
\text { CFL }\end{array}$ \\
\hline \multirow{6}{*}{$\begin{array}{r}\text { Number of Fixtures } \\
\text { Lamps per Fixture } \\
\text { Fixture Wattage } \\
\text { LF - Load Factor } \\
\text { Annual Operating Hours } \\
\text { Conversion Factor }\end{array}$} & 150 & 20 & 45 & 54 & 125 & 95 & 140 & 16 & 6 \\
\hline & 1 & 1 & 1 & 1 & 1 & 1 & 1 & 1 & 1 \\
\hline & 2 & 150 & 16 & 16 & 4 & 16 & 4 & 150 & 16 \\
\hline & 1 & 1 & 1 & 1 & 1 & 1 & 1 & 1 & 1 \\
\hline & 8,760 & 1,000 & 4,000 & 8,760 & 8,760 & 8,760 & 8,760 & 2,080 & 2,080 \\
\hline & 1,000 & 1,000 & 1,000 & 1,000 & 1,000 & 1,000 & 1,000 & 1,000 & 1,000 \\
\hline
\end{tabular}

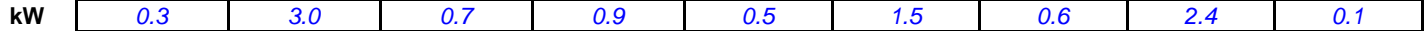

\begin{tabular}{c|c|c|c|c|c|c|c|c|c|}
\multirow{2}{*}{$\mathrm{kWh} /$ Yr Use } & 2,628 & 3,000 & 2,880 & 7,534 & 4,380 & 13,315 & 4,906 & 4,992 & 208 \\
\cline { 2 - 10 }
\end{tabular}

Annual Energy Cost

\begin{tabular}{|l|l|l|l|l|l|l|l|l|}
\hline$\$ 184$ & $\$ 210$ & $\$ 202$ & $\$ 527$ & $\$ 307$ & $\$ 932$ & $\$ 343$ & $\$ 349$ & $\$ 15$ \\
\hline
\end{tabular}

\section{SAVINGS}

\begin{tabular}{|c|c|c|c|c|c|c|c|c|c|}
\hline \multirow{3}{*}{$\begin{array}{r}k W \\
k W h / Y r \text { Use } \\
\text { Annual Energy Cost }\end{array}$} & 1.4 & 6.2 & 6.0 & 2.7 & 1.8 & 4.7 & 2.2 & 4.9 & 0.8 \\
\hline & 11,826 & 6,160 & 24,120 & 23,214 & 15,768 & 40,822 & 19,622 & 10,254 & 1,664 \\
\hline & $\$ 828$ & $\$ 431$ & $\$ 1,688$ & $\$ 1,625$ & $\$ 1,103$ & $\$ 2,858$ & $\$ 1,374$ & $\$ 718$ & $\$ 116$ \\
\hline \multirow{3}{*}{$\begin{array}{r}\text { Project cost Estimate } \\
\text { Incentive } \\
\text { Simple Payback }\end{array}$} & $\$ 1,463$ & $\$ 2,540$ & $\$ 716$ & $\$ 859$ & $\$ 1,331$ & $\$ 1,511$ & $\$ 1,491$ & $\$ 2,032$ & $\$ 95$ \\
\hline & $\$ 300$ & $\$ 1,200$ & $\$ 180$ & $\$ 216$ & $\$ 250$ & $\$ 380$ & $\$ 280$ & $\$ 960$ & $\$ 24$ \\
\hline & 1.4 & 3.1 & 0.3 & 0.4 & 1.0 & 0.4 & 0.9 & 1.5 & 0.6 \\
\hline
\end{tabular}




\section{Summary}

\begin{tabular}{|l|r|r|r|r|r|r|}
\hline & & & annual & & & \\
\hline vendor & kW saved & kWh saved & $\mathbf{\$}$ saved & project cost & incentive & payback \\
\hline Midwest Lighting & 48.92 & 279759 & $\$ 19,582.05$ & $\$ 19,047.35$ & $\$ 7,249.00$ & 0.603 \\
\hline Energy Solutions & 32.07 & 146587 & $\$ 10,260.38$ & $\$ 13,802.14$ & $\$ 5,271.15$ & 0.831 \\
\hline United Electric & 30.62 & 153450 & $\$ 10,740.99$ & $\$ 12,036.75$ & $\$ 3,790.00$ & 0.768 \\
\hline
\end{tabular}

attachment d 


\section{Conservation Efforts}

1. Individual offices have their own supply of rechargeable batteries and charging units.

2. Incandescent light bulbs changed out to CFLs and LEDs.

3. Can slot machines be changed out to LEDS? Can manufacturers be asked to use better energy efficiency options when building these?

4. Double sided printing, reuse junk mail and throwaways for notes etc.

5. Soy based printer ink, refillables. ??

6. Motion Sensors for outdoor lighting as well as places like bathrooms and rooms that are infrequently used.

7. Recycled and PCW items.

8. Weatherization \& Insulation on all buildings

9. Set faxes to be received via email, then decide if its important enough to print.

10. Recycling Program tribal wide.

11. Energy Star Products replacements when old fail or are outdated

12. Switching to more energy efficient light sources (super 8s?) 


\section{$\underline{\text { Renewable Energy Option Sites }}$}

1. Possible Wind Sites:

a)Casino/Lodge/Cstore/public works/CDC- fields

a) College Farm (RESDI,Headstart,Mide

b) WOJB tower

c) Tribal Office/Clinic/Housing/WOJB

2. PV Sites:

a) Casino \& Lodge

b) Ojibwe Woodcrafters

c) Tribal Office

d) School

e) Wojb

3. Solar Thermal Sites:
a) Lodge
b) Tribal Office
c) Residential 